\title{
KEDUDUKAN JANJI DALAM UNDANG-UNDANG ISLAM DAN AKTA KONTRAK 1950
}

\section{Status of Promise in Shariah Law and Contract Act 1950}

\author{
Fadziani Yaakub \\ Ph.D Candidate, Department of Shariah and Law, \\ Academy of Islamic Studies, \\ University of Malaya, 50603 Kuala Lumpur. \\ fadzianiyaakub@yahoo.com \\ Ahmad Hidayat Buang \\ Professor, Department of Shariah and Law, \\ Academy of Islamic Studies, \\ University of Malaya, 50603 Kuala Lumpur. \\ ahidayat@um.edu.my
}

\begin{abstract}
This paper examines the status of promise in the contracts of Islamic banking and finance in comparison with Malaysia Contract Act 1950. It is accepted that the law applicable to all commercial contracts in Malaysia is governed by Federal law. No doubt that Islamic banking contracts are based on the principles of Shariah. However certain aspects of the Shariah may not be consistent with the Contract Act. Using qualitative analysis on the reading materials available and judgement of the case law, the authors conclude that there is a different between Islamic Shariah and Contract Act in respect of promise, where the former considers it as non-binding and the latter binding. Using juridical methods of Islamic jurisprudence the modern scholars of Shariah have proposed that promise in the modern Islamic banking contracts is also binding as this would protect the interest of the parties. By doing this the status of promise in both legal system is binding and thus avoiding any conflicts of law between Islamic Shariah and Malaysia Contract Act 1950.
\end{abstract}

Keywords: wa'd, promise, Islamic Law, Contract Act 1950, Islamic Banking \& Finance 


\section{PENDAHULUAN}

Janji ialah pernyataan kesediaan untuk melakukan atau memberi sesuatu (Dewan Bahasa dan Pustaka, 2002: 518). Menepati janji antara salah satu nilainilai murni yang dituntut oleh masyarakat dan juga agama. Mereka yang tidak menepati janji bukan sahaja dipandang serong oleh masyarakat malah dikecam oleh Islam. Sebagaimana hadis yang diriwayatkan oleh Abū Hurayrah, sabda Rasulullah SAW:

$$
\text { اية المنافت ثلاث: إذا حدث كذب و إذا وعد أخلف وإذا اؤتن خان }
$$

"Tanda-tanda seseorang itu munafik ada tiga: apabila dia bercakap dia berbohong, apabila dia berjanji dia memungkiri dan apabila diberi amanah dia mengkhianati..." 1

Pada masa kini, janji memainkan peranan penting bukan sahaja dikomunikasikan dalam masyarakat malah digunakan dalam transaksi perniagaan terutamanya dalam sektor perbankan. Janji yang dimaksudkan dalam perbankan Islam ialah merupakan suatu jaminan oleh seseorang kepada pihak lain bahawa mereka akan melakukan sesuatu atau tidak melakukan sesuatu. Oleh itu, ia bersifat sebagai alat kawalan risiko yang digunakan untuk mencipta produk-produk yang inovatif dan kompetitif kerana prinsip ini digunakan secara meluas dalam pelbagai kemudahan pembiayaan dan pelaburan (Nurdianawati Irwani Abdullah, 2010: 84-85) seperti ijārah muntahiyah bi al-tamlik (lease ending with ownership), ijārah thumma al-bay ' (Islamic hire-purchase), mushārakah mutanaqisah (diminishing partnership), produkproduk lindung nilai seperti Islamic forward forex, Islamic profit rate swaps dan Islamic cross currency swaps dan juga digunakan dalam penstrukturan sukuk (Marjan Muhammad et al., 2011: 2). Tambahan pula, berdasarkan kepada amalan semasa institusi kewangan dan perbankan Islam menjalankan perniagaan mereka melalui kontrak yang berasaskan kepada pengaplikasian janji yang mengikat iaitu janji boleh dikuatkuasakan di mahkamah sekiranya terdapat pihak yang memungkiri janji dan dikenakan pampasan atau ganti rugi kepada pihak yang menanggung kerugian atau kehilangan akibat kemungkiran tersebut. (Mohamad Akram Laldin, 2009: 3-4).

Undang-undang yang terpakai untuk menguatkuasakan perjanjian di Malaysia ialah Akta Kontrak (AK) 1950 dan di bawah akta tersebut juga terdapat peruntukkan mengenai janji. Persoalannya sejauh mana prinsip janji boleh dikuatkuasakan di bawah akta tersebut dan adakah janji yang

1 Diriwayatkan oleh al-Bukhārī, Fatḥ al-Bārī Sharḥ Saḥ̄ḥ al-Bukhārī, Bāb Man Amara bi Injazi al-Wa'd wa Fa'alahu al-Hasan, no. Hadis 2682. 
dimaksudkan di bawah AK 1950 menepati prinsip janji dalam undang-undang Islam. Sebagaimana yang disebut oleh Tun Abdul Hamid (2010: 8):

"Sama ada prinsip janji dalam undang-undang Islam perlu dijadikan kontrak yang mengikat dan bagaimana untuk menguatkuasakannya."

Kajian ini bertujuan untuk mengkaji status janji dalam undang-undang Islam dan AK 1950 dengan menggunakan kaedah kualitatif dan analisis secara kualitatif deskriptif serta perbandingan. Kajian ini mendapati terdapat persamaan maksud antara janji dalam undang-undang Islam dan AK 1950. Walau bagaimanapun, kedua-dua prinsip ini memberi kesan atau implikasi yang berbeza.

\section{PERMASALAHAN KAJIAN}

Terdapat sesetengah penulis berpendapat janji yang diaplikasikan dalam produk-produk perbankan dan kewangan Islam adalah mengikat iaitu boleh dikuatkuasakan dari segi undang-undang. Tujuannya ialah untuk menjaga kepentingan pihak-pihak (Nurdianawati Irwani Abdullah, 2010: 95), kestabilan dalam urusan kewangan (Suraiya Osman \& Abdullah Jalil, 2013: 11; Azlin Alisa Ahmad et al., 2012: 40), dan juga sebagai alat kawalan risiko (Jasani Abdullah \& Munawwaruzzaman Mahmud, 2008: 2). Ini bermakna, mereka yang memungkiri janji boleh dikenakan pampasan atau ganti rugi (ta 'wiḍ) berdasarkan kepada kerugian sebenar yang ditanggung oleh pihak bank akibat daripada kemungkiran janji tersebut dan sekiranya pelanggan enggan untuk membayar pampasan tersebut, pihak bank boleh membawa kes tersebut ke mahkamah (Saadiah Mohamad et al., 2011: 3).

Menurut Nurdianawati Irwani Abdullah (2010: 96) dan Ismail Wisham et al. (2011: 232) hak penerima janji bukan sahaja dilindungi oleh undangundang Islam malah oleh undang-undang sivil iaitu di bawah undang-undang kontrak terdapat pengiktirafan kepada janji sebelah pihak (unilateral promise) dan bilateral promise serta tentang doktrin equity yang diaplikasikan untuk memberi perlindungan kepada penerima janji.

Jasani Abdullah dan Munawwaruzzaman Mahmud (2008: 10) berkata penggunaan janji bukanlah suatu fenomena baru dari sudut perundangan kerana ia digunakan secara meluas dalam dokumentasi perundangan dan mengambil pendapat yang mengatakan janji merupakan satu kontrak yang sah dan boleh dibicarakan di mahkamah. Mereka juga bersetuju dengan pandangan yang mengatakan janji yang dibuat perlu mengandungi balasan (consideration) untuk menjadikannya sah di sisi undang-undang. Pendapat ini turut disokong 
oleh Mustafa 'Afifi Halim et al. (2009: 234) supaya diwujudkan elemen balasan dalam prinsip janji bagi membolehkannya memenuhi elemen-elemen pembentukan kontrak menurut undang-undang kontrak.

Ini kerana, di bawah AK 1950 terdapat peruntukan mengenai janji yang dinyatakan di bawah seksyen 2(a), (b), (c), (d) dan (e). Peruntukan tersebut menyebut janji membentuk kontrak apabila memenuhi kriteria-kriteria berikut seperti terdapat penerimaan kepada janji sama ada penerimaan melalui perbuatan atau janji berbalas, wujudnya balasan (consideration), niat untuk mewujudkan obligasi dan sebagainya. Oleh itu, sekiranya berlaku kemungkiran janji penerima janji boleh menuntut ganti rugi di bawah AK 1950 atau dalam bentuk pelaksanaan spesifik di bawah Akta Relif Spesifik 1950.

Walau bagaimanapun, masih belum terdapat kes-kes yang melibatkan penguatkuasaan atau kemungkiran janji dalam perbankan Islam dibicarakan atau diputuskan di mahkamah (Nor Adila Mohd Noor \& Mohd Ashraf Aripin, 2010: 88; Hakimah Yaacob, 2011: 2). Oleh itu, tiada keputusan kes-kes yang boleh dirujuk kecuali kepada penulisan yang dibuat oleh ulama silam dan kontemporari (Ibid, 2010: 88). Untuk memberi kepastian dan pengiktirafan terhadap wa' $d$ di dalam AK 1950 satu usaha sedang dibuat oleh Jawatankuasa Harmonisasi (Committee Harmonisation) BNM untuk memasukkan wa'd dalam AK 1950 (Tun Abdul Hamid Mohamad, 2013: 6).

\section{STATUS JANJI DALAM UNDANG-UNDANG ISLAM}

Pengaplikasian prinsip janji dalam institusi kewangan dan perbankan Islam dibahagikan kepada tiga, iaitu wa'd (unilateral promise), muwā'adah (bilateral promise) dan wa'adan (two unilateral promise). Ketiga-tiga jenis janji ini mempunyai implikasi hukum yang berbeza-beza. Wa'd ialah janji yang diberikan oleh sebelah pihak sahaja (pelanggan atau bank) kepada pihak yang satu lagi (promisee) untuk melakukan sesuatu di masa hadapan (Aznan Hasan, 2008: 1). Majoriti ulama kontemporari membenarkan pengaplikasian wa'd (unilateral promise) mengikat pihak-pihak yang berjanji (promisor) dan boleh menguatkuasakannya di mahkamah sekiranya pembuat janji memungkiri janjinya (Marjan et al., 2011: 12; Nurdianawati Irwani Abdullah 2010: 95, Ismail Wisham et al., 2011: 232). Akademi Fiqh Antarabangsa (1988) dan Auditing Organization for Islamic Financial Institution (AAIOFI) (2010) dalam resolusinya memutuskan bahawa $w a$ ' $d$ mengikat dari sudut perundangan apabila janji tersebut dikaitkan dengan sesuatu sebab dan penerima janji telah menanggung kos tersebut kesan kepada janji tersebut. 
Muwā 'adah berbeza dengan $w a$ ' $d$ kerana ia melibatkanjanji daripada keduadua belah pihak iaitu janji daripada pembuat janji (promisor) dan penerima janji (promisee) iaitu mereka saling berbalas janji. Majoriti ulama seperti Akademi Fiqh Antarabangsa (1998 \& 2006), AAIOFI (2010: 109), Dallah Barakah dan Kuwait Finance House (KFH) (t.t.) tidak membenarkan penggunaannya secara mulzim (mengikat) kedua-dua belah pihak kerana dikatakan menyerupai kontrak ( 'aqd). Walau bagaimanapun, pengaplikasiannya dibenarkan sekiranya keduadua belah pihak diberikan hak khiyār (pilihan) untuk membatalkan janji tersebut dan terdapat keperluan umum untuk menjadikan muwā'adah mulzimah secara undang-undang atau uruf industri antarabangsa (Akademi Fiqh Antarabangsa, 1998 dan 2006). Sebagaimana menurut Humayon Dar (2010: 12), muwā'adah yang mengikat kedua-dua pihak (promisor \& promisee) dianggap sebagai kontrak apabila tiada pilihan (option) yang diberikan kepada kedua-dua pihak tersebut. Bank Negara Malaysia (BNM) (2010: 139) dalam resolusinya yang terdahulu tidak membenarkan penggunaan muwā'adah mulzimah kerana dikatakan menyerupai kontrak. Namun, dalam mesyuarat Majlis Penasihat Syariah (MPS) BNM ke-157 yang diadakan pada 31 Mac 2015 memutuskan muwā 'adah mulzimah dibenarkan kerana pengaplikasiannya berbeza dengan kontrak. $^{2}$

Terdapat juga pendapat yang mengatakan muwa' 'adah mulzimah tidak dianggap sebagai kontrak (Khairun Najmi Saripudin et al., 2012: 163; Azlin Alisa Ahmad, 2012: 10) kerana muwā'adah hanyalah semata-mata janji untuk melaksanakan kontrak pada masa hadapan dan kontrak akan terbentuk atau berlaku pada suatu tarikh yang dipersetujui tersebut. Mereka juga berpandangan bahawa perbahasan mengenai larangan atau ketidakharusan muwā 'adah mulzimah tidak berasaskan kepada sumber yang kuat kerana tidak terdapat dalil untuk menyokong pandangan beberapa ulama yang menganggap muwā 'adah mulzimah adalah kontrak (Khairun Najmi Saripudin et al., 2012: 163). Noor Mohammed (1988: 123-124) menyebut bahawa kontrak dalam undang-undang Islam tidak terbentuk melalui pertukaran janji tetapi melalui pertukaran persetujuan (grant) iaitu tawaran (ijab/offer) dan penerimaan (qabül/acceptance). Kenyataan ini disokong oleh Ahmad Hidayat Buang (2000: 3) dan Siti Salwani Razali (2010: 4) iaitu kontrak yang sah terbentuk apabila mengandungi persetujuan (consent) daripada pihak-pihak yang boleh dicapai melalui lafaz tawaran dan penerimaan. Selain itu, menurut Muhammad Hisyam Mohamad (2014: 77) janji yang mengikat dengan kontrak adalah sesuatu yang berbeza kerana janji tidak memenuhi ciri-ciri kontrak iaitu tidak

2 Bank Negara Malaysia (BNM), "The Shari'ah Advisory Council of Bank Negara Malaysia (the SAC) $157^{\text {th }}$ Meeting," http://www.bnm.gov.my/index.php?ch=en about\&pg=en_sac_updates\&ac=445, dicapai pada 19 Oktober 2015. 
memberi kesan yang segera kepada objek (subject) kontrak tetapi memberi kesan pada masa akan datang.

Wa'adan pula merupakan istilah baharu yang diperkenalkan dalam pasaran kewangan Islam semasa (Shabana Hasan \& Marjan Muhamad, 2011: 136) yang bermaksud dua janji yang diberikan secara unilateral (two promises) oleh satu pihak kepada pihak yang lain, dan begitu juga sebaliknya, dan dua janji ini tidak saling berkaitan dan pelaksanaannya adalah bergantung pada dua syarat yang berbeza (Aznan Hasan, 2008: 1). Oleh kerana ia diperkenalkan pada masa kini maka tidak terdapat atau tidak ditemui perbincangan mengenai wa'adan oleh ulama silam (Khairun Najmi Saripudin et al., 2012: 161). Prinsip ini banyak digunakan dalam penstrukturan sukuk (Aznan Hasan, 2008: 9) seperti dalam Ingress Sukuk al-Ijarah, Dubai Sukuk Center Limited (Shabana Hasan \& Marjan Muhammad, 2011: 137), PTC Haluan Gigih Sdn Bhd (Khairun Najmi Saripudin et al., 2012: 164). Menurut Aznan Hasan (2008: 7) pengaplikasian wa 'adan dibenarkan sekiranya memenuhi syarat-syarat berikut iaitu dua syarat yang diberikan tersebut membawa kepada dua kesan yang berbeza kerana sekiranya dua syarat yang diberikan tersebut membawa kepada kesan yang sama dibimbangi menyerupai muwā'adah.

\section{STATUS JANJI (PROMISE) DALAM AKTA KONTRAK 1950}

Dengan menjadikan janji sebagai mulzim, maka sebarang kemungkiran janji oleh pihak-pihak boleh dikuatkuasakan di mahkamah. Berdasarkan kepada Perlembagaan Persekutuan dalam Jadual Sembilan senarai I Kerajaan Persekutuan memperuntukkan hanya Mahkamah sivil sahaja yang mempunyai bidang kuasa untuk memutuskan kes-kes mengenai kontrak dan perniagaan (Ahmad Ibrahim, 2000: 5). Manakala bidang kuasa Mahkamah Syariah terhad dan terpakai kepada orang Islam sahaja (Ruzian Markom et al., 2013: 3) sebagaimana yang disebut dalam Butiran II Senarai Negeri Perlembagaan Persekutuan (PP) iaitu meliputi perkara yang berkaitan dengan undang-undang diri orang Islam seperti perkahwinan, perceraian, penjagaan anak, nafkah, pengambilan anak angkat, taraf anak, undang-undang keluarga, pemberian atau pewarisan harta berwasiat dan tidak berwasiat (Perkara 4(e)(ii) Butiran I, Senarai Persekutuan Jadual Kesembilan, Perlembagaan Persekutuan).

Dalam kes Bank Islam Malaysia Berhad v. Adnan Omar \& Ors [1994] 3 CLJ 735 hakim memutuskan Mahkamah Syariah tidak berbidangkuasa untuk mendengar kes-kes perbankan Islam kerana Bank Islam iaitu plaintifmerupakan satu badan korporat dan bukan orang perseorangan yang tidak mempunyai sebarang agama dan perkara yang berhubung dengan perbankan, kewangan dan insurans termasuk dalam bidang kuasa persekutuan sebagaimana yang 
dinyatakan dalam perkara 7 dan 8 Butiran I Senarai Persekutuan Jadual Sembilan Perlembagaan Persekutuan iaitu perkara yang berkaitan dengan kewangan, tred, perdagangan dan perusahaan.

Hakim dalam kes Bank Kerjasama Rakyat Malaysia Berhad v. Emcee Corporation Sdn Bhd [2003] 1 CLJ 625 menyebut:

"Walaupun perkhidmatan yang ditawarkan ialah kemudahan perbankan Islam undang-undang yang terpakai adalah sama juga dengan undang-undang yang terpakai kepada perbankan konvensional seperti AK 1950, Kanun Tanah Negara (KTN) 1965 , Akta Jualan Barang (AJB) 1957 dan undang-undang substantif yang lain..."

Keadaan ini menunjukkan sebarang aktiviti atau operasi perbankan Islam perlu patuh kepada undang-undang atau peraturan-peraturan yang ingin mereka jalankan dalam perniagaan tersebut dan dalam masa yang sama perlu patuh dengan prinsip dan undang-undang Syariah (Sudin Haron \& Wan Nursofiza Wan Azmi, 2009: 259).

Oleh itu, untuk menguatkuasakan prinsip janji rujukan perlu dibuat kepada AK 1950 memandangkan undang-undang yang mengawal selia transaksi kontrak di Malaysia adalah AK 1950 (Visu Sinnadurai, 2011: 1) dan di bawah akta tersebut memperuntukkan status janji. Sebagaimana yang dinyatakan dalam seksyen 2(b) AK 1950 iaitu:

"Apabila orang kepada siapa cadangan itu dibuat menyatakan persetujuan dengan cadangan itu diterima; sesuatu cadangan bila diterima, adalah menjadi janji..."

Peruntukkan ini menyatakan janji terbentuk apabila terdapat penerimaan kepada cadangan tersebut. Keadaan ini bermaksud janji terbentuk apabila terdapat cadangan dan penerimaan. Tanpa penerimaan tersebut ia tidak dapat menukarkan cadangan menjadi janji. Definisi cadangan boleh dilihat dalam seksyen 2(a) AK 1950 iaitu:

“apabila seseorang menyatakan kesediaannya kepada seseorang yang lain untuk melakukan atau menahan diri dari melakukan sesuatu, dengan maksud untuk memperoleh persetujuan orang itu untuk berbuat sesuatu atau menahan diri dari berbuat seseorang itu, maka bolehlah dikatakan bahawa orang itu membuat cadangan."

Untuk menjadikan cadangan itu sah dan boleh dikuatkuasakan undangundang perlu memenuhi kriteria-kriteria berikut iaitu cadangan mesti 
mengikut undang-undang yang diterima (Abdul Mohaimin Noordin Ayus, 2000: 154), jelas dan tertentu (S. Santhana Dass, 2005: 31 ), cadangan boleh dibuat secara bersyarat dan tidak bersyarat (Eckhardt Marine GMBHv. Sheriff, High Court of Malaya, Seremban \& Ors, [2001] 4 MLJ 54), dan cadangan tersebut perlu dikomunikasikan (Seksyen 4(1) AK 1950). Apabila terdapat cadangan ia menjadi janji apabila terdapat penerimaan dan dengan penerimaan tersebut akan membawa kepada pembentukan kontrak (J.W Carter \& D.J Harland, 2002: 41).

Penerimaan didefinisikan sebagai persetujuan muktamad dan tidak bersyarat kepada terma-terma cadangan yang dibuat mengikut cara-cara yang ditetapkan atau ditentukan oleh pencadang (Stephen Grew, 2005: 71). Ia membawa maksud penerimaan yang dibuat mestilah bersesuaian dan selari mengikut kepada terma-terma cadangan supaya menjadi penerimaan yang sah di bawah akta kontrak (Eckhardt Marine GMBH v. Sheriff, High Court of Malaya, Seremban \& Ors [2001] 4 MLJ 54). Sekiranya penerimaan tersebut tidak selari dengan cadangan ia menjadi cadangan balas (counter-offer) yang menyebabkan cadangan asal terhapus dan membentuk cadangan baru. Dan penerimaan kepada cadangan ini tertakluk kepada syarat-syarat tertentu untuk membolehkan cadangan tersebut bertukar menjadi janji seperti penerimaan tersebut mestilah mutlak dan tidak bersyarat dan dinyatakan secara biasa dan munasabah melainkan jika pencadang menetapkan cara penerimaannya (seksyen 7 (a) (b) AK 1950). Dan orang yang membuat cadangan ialah pembuat janji dan orang yang menerima cadangan ialah penerima janji (seksyen 2(c) AK 1950).

Selain itu, di bawah undang-undang kontrak juga terdapat peruntukan mengenai unilateral promise, bilateral promise, remedi atau ganti rugi dan juga doktrin ekuiti (Nurdianawati Irwani Abdullah, 2010: 96). Kerana itu, menurut Ismail Wisham et al. (2011: 232) hak penerima janji dilindungi sama ada oleh undang-undang Islam atau undang-undang kontrak di mana pihak-pihak yang mengalami kerugian akibat kemungkiran janji boleh menguatkuasakan di mahkamah. Kedudukan unilateral promise dan bilateral promise di dalam AK 1950 boleh dilihat kepada seksyen 8 AK 1950 yang menyebut:

\footnotetext{
"penunaian syarat-syarat sesuatu cadangan, atau penerimaan mana-mana balasan untuk janji berbalas yang boleh ditawarkan dengan satu cadangan, adalah penerimaan cadangan itu..."
}

Kontrak unilateral bermaksud mana-mana cadangan atau janji daripada pembuat janji dipenuhi melalui tindakan atau perbuatan penerima janji tanpa janji berbalas atau melalui pertukaran janji seperti dalam kontrak berbentuk bilateral (Australian Woollen Mills Pty Ltd v. Commonwealth [1954] 92 CLR 
424). Dalam kontrak unilateral ini hanya satu pihak sahaja iaitu pembuat janji sahaja yang bertanggungan atau bertanggungjawab (obligated) untuk melaksanakan janjinya apabila janji tersebut dilaksanakan oleh penerima janji (Australian Woollen Mills Pty Ltd v. Commonwealth, [1954] 92 CLR 424). Ini bermaksud penerima janji tidak terikat atau berkewajipan (obligation) untuk melaksanakan atau menerima janji oleh pembuat janji. Contohnya berjanji untuk memberi ganjaran bagi sesiapa yang menjumpai barang kehilangannya. Dalam kes Carlil v. Carbolic Smoke Ball Co [1983] QB 256 penerimaan plaintif kepada tawaran daripada syarikat Carbolic Smoke Ball Co telah membentuk kontrak unilateral antara plaintif dengan defendan apabila plaintif menggunakan ubat tersebut mengikut arahan yang terkandung dalam ubat tersebut. Perbuatan plaintif menggunakan ubat tersebut mengikut syarat yang disediakan membentuk kontrak unilateral.

Berbeza pula dengan kes yang melibatkan kontrak bilateral yang memerlukan pelaksanaan daripada kedua-dua belah pihak (Stephen Grew, 2005: 35). Ini membawa maksud kontrak bilateral terbentuk melalui pertukaran janji antara pembuat janji dengan penerima janji yang dipanggil sebagai janji berbalas.

"Janji yang merupakan balasan atau sebahagian balasan untuk pihak masing-masing adalah disebut janji berbalas (reciprocal premises)."

Walaupun kedua-dua pihak belum lagi melaksanakan atau melakukan perkara yang dijanjikan, tetapi janji berbalas tersebut akan membentuk kontrak dan mengikat kedua-dua pihak yang berjanji. Keadaan ini dinyatakan oleh seksyen 2(e) Akta Kontrak 1950:

"Setiap janji dan setiap set janji, yang menjadi balasan pihak masing-masing, adalah suatu perjanjian."

Walaupun AK 1950 menyebut tentang kedudukan unilateral promise dan juga bilateral promise, namun janji yang dimaksudkan oleh AK 1950 membawa kepada pembentukan kontrak sedangkan prinsip janji menurut undang-undang Islam hanya semata-mata janji untuk memasuki kontrak pada masa hadapan yang mana kontrak tidak akan terbentuk hanya melalui janji sebaliknya kontrak terbentuk melalui lafaz $\bar{\jmath} j a b$ dan qabül. 


\section{PERBINCANGAN DAN HASIL KAJIAN}

Berdasarkan kepada penjelasan yang diberikan dapat disimpulkan bahawa terdapat persamaan dan perbezaan status janji dalam undang-undang Islam dan AK 1950. Perbandingan tersebut adalah sebagaimana berikut:

\section{Persamaan}

Penulis dapati terdapat persamaan maksud dari sudut istilah atau terminologi antara janji dalam undang-undang Islam dan AK 1950 yang melibatkan kepada pengaplikasian prinsip wa'd (unilateral promise), muwā'adah (bilateral promise) dan wa'adan (two unilateral promise):

\section{a) Wa'd \& Unilateral Contract}

Menurut kepada definisi yang diberikan oleh Aznan Hasan (2008: 1) wa'd ialah janji dari sebelah pihak (unilateral promise) yang diberikan kepada suatu pihak yang lain untuk melakukan sesuatu perkara, seperti janji untuk menjual atau membeli. Contohnya dalam kontrak murābahah hanya pelanggan yang berjanji dengan bank bahawa ia akan membeli daripada bank selepas bank mendapatkan aset yang dikehendaki olehnya dan berdasarkan janji daripada pelanggan tersebut bank mendapatkan aset tersebut dan selepas itu mereka akan memasuki kontrak murābahah (BNM, 2013: 26). Begitu juga unilateral promise dalam AK 1950 di mana hanya satu pihak sahaja yang berjanji dan satu pihak lagi bertindak atau melaksanakan sesuatu berdasarkan kepada janji tersebut tanpa janji berbalas daripada pihak satu lagi. Dan pelaksanaan kepada janji tersebut akan membawa kepada pembentukan unilateral kontrak di bawah AK 1950.

\section{b) Muwā'adah \& Bilateral Contract}

Berbeza pula dengan muwā'adah di mana kedua-dua pihak saling berjanji untuk menjalankan pertukaran di masa hadapan iaitu dua janji tersebut diberi secara timbal balik (bilateral) oleh dua pihak, satu kepada yang lain, sama ada janji tersebut boleh dibuat secara bersyarat atau tidak (Aznan Hasan, 2008: 1). Contohnya A berjanji untuk menjual keretanya kepada B dengan harga RM100,000 pada 1 Mei 2011 dan B pula berjanji untuk membeli kereta A dengan harga RM100,000 pada 1 Mei 2011 (Khairun Najmi Saripudin et al., 2012: 161). Keadaan ini sama dengan bilateral kontrak dalam AK 1950 iaitu kedua-dua pihak saling berbalas janji untuk melakukan sesuatu pada 
masa hadapan. Dan di bawah AK 1950 kontrak terbentuk walaupun keduadua pihak belum lagi melaksanakan janjinya tetapi kontrak terbentuk melalui janji-janji yang diberikan.

\section{c) Wa'adan \& Counter Offer}

Wa'adan ialah dua janji yang diberikan secara unilateral oleh satu pihak kepada pihak yang lain, dan begitu juga sebaliknya, dan dua janji ini tidak saling berkaitan dan pelaksanaannya adalah bergantung pada dua syarat yang berbeza (Aznan Hasan, 2008: 1). Prinsip wa'adan ini menyerupai prinsip counter-offer dalam undang-undang kontrak. Counter-offer berlaku apabila penerimaan yang berlaku adalah berlainan dengan sesuatu cadangan yang ditujukan kepadanya. Contohnya, A menawarkan kepada B untuk menjual keretanya dengan harga RM20,000 dan B bersetuju untuk membelinya tetapi dengan harga RM15,000. Dalam undang-undang kontrak counter-offer tidak akan membentuk kontrak kerana tidak berlaku penerimaan kepada cadangan asal sebaliknya membentuk satu cadangan baru yang memerlukan kepada penerimaan.

\section{Perbezaan}

Walaupun terdapat persamaan maksud dari sudut terminologi antara janji dalam undang-undang Islam AK 1950 tetapi dari sudut pengaplikasian dan kesan kedua-dua prinsip tersebut adalah berbeza. Perbezaan tersebut adalah sebagaimana berikut:

\section{a) Cadangan (Ījāb) \& Penerimaan (Qabūl)}

Janji dalam AK 1950 terbentuk apabila terdapat penerimaan (acceptance) kepada sesuatu cadangan (proposal). Cadangan dan penerimaan ini merupakan elemen utama kepada pembentukan kontrak. Sekiranya tidak terdapat penerimaan kepada cadangan tersebut, maka cadangan tersebut kekal sebagai cadangan dan tidak akan bertukar menjadi janji. Maksud cadangan ini boleh dilihat dalam kes Preston Corporation Sdn Bhd v. Edward Leong [1982] 2 MLJ 22 apabila hakim mahkamah persekutuan pada masa itu iaitu Salleh Abbas menyatakan bahawa:

"Tawaran ialah pemberitahuan kesediaan pembuat tawaran untuk memasuki kontrak yang mengikat secara perundangan sama ada terma-terma yang dinyatakan secara tersirat atau nyata mesti menunjukkan bahawa ia menjadi mengikat pembuat 
tawaran (offeror) sebaik sahaja diterima oleh penerima tawaran (offeree)."

Merujuk kepada definisi cadangan yang diberikan oleh Salleh Abbas ialah untuk memberitahu 'kesediaan' pihak untuk berkontrak apabila cadangan tersebut diterima dan cadangan tersebut menjadi janji. Keadaan ini menunjukkan bahawa janji yang dimaksudkan di bawah AK 1950 yang membawa kepada pembentukan kontrak kerana mengandungi cadangan dan juga penerimaan. Ini berbeza dengan janji dalam undang-undang Islam yang merujuk kepada komitmen yang dibuat oleh seseorang kepada pihak lain untuk melaksanakan sesuatu yang dapat memberi manfaat kepada pihak satu lagi (Azlin Alisa Ahmad et al., 2012: 5). Mengikut undang-undang Islam pengaplikasian janji tidak membawa kepada pembentukan kontrak kerana tidak mengandungi cadangan ( $\bar{j} \bar{a} b)$ dan juga penerimaan (qabu $\bar{l})$ (Ibid, 2012: 41).

Dalam Resolusi yang dikeluarkan oleh BNM (2012: ) perbezaan antara kontrak dan janji boleh dilihat daripada kesan perundangan. Resolusi tersebut menyebut:

"Each of them has its own legal implications. In a contract, the parties are bound by the terms of the contract, thus they may be obliged to compensate for the breach of the contract. On the other hand, in a promise it is not binding on the promisor to fulfill his promise. As such, no compensation could be imposed on him if he breaches of the promise."

Selain itu, menurut Noor Muhammad (1988: 124) kontrak dalam undangundang Islam bukan merupakan perjanjian kerana ia tidak terbentuk melalui janji tetapi sebaliknya adalah melalui keizinan atau persetujuan (grant) yang boleh dicapai melalui lafaz tawaran dan penerimaan.

\section{b) Remedi atau Ganti Rugi}

Antara lain perbezaan janji dalam undang-undang Islam dengan janji AK 1950 ialah dari segi tuntutan kepada pampasan atau ganti rugi akibat daripada kemungkiran janji. Walaupun janji dalam undang-undang Islam bukan kontrak tetapi undang-undang membenarkan pihak yang mendapat kerugian untuk menuntut jumlah kerugian yang dialaminya di bawah kaedah quantum meruit iaitu remedi atau ganti rugi yang sepatutnya diterima berdasarkan kerja-kerja yang dijalankan oleh plaintif atau defendan (Mustafa 'Afifi Ab Halim et al., 2009: 234). 
Dalam resolusi BNM (2013: 27) menggariskan jumlah pampasan yang dikenakan kepada pihak yang memungkiri janji adalah mengikut kos sebenar yang ditanggung oleh perbankan Islam dalam pelupusan aset tersebut kepada pihak ketiga dan juga harga yang lebih rendah berbanding harga semasa. Contohnya, dalam kes melibatkan kontrak murābahah, pelanggan meminta pihak bank untuk mendapatkan mesin yang bernilai RM50,000 dan berjanji (unilateral promise) untuk membeli mesin tersebut selepas bank memperolehinya. Berdasarkan kepada janji tersebut bank mendapatkan mesin yang dikehendaki oleh pelanggan. Selepas pembelian tersebut, pelanggan enggan memasuki kontrak murābahah iaitu enggan membeli mesin tersebut dan telah memungkiri janjinya. Bank melupuskan aset tersebut sebanyak RM45,000 dan kos tambahan yang ditanggung akibat pelupusan tersebut ialah RM2,500. Maka pelanggan akan dikenakan pampasan sebanyak RM7,500. Pihak bank tidak boleh menuntut ganti rugi selain daripada kerugian sebenar yang ditanggung olehnya.

Cara pengiraan:
RM 50,000 - RM 45,000 $=$ RM 5,000 + (RM 2,500)
Jumlah $=$ RM 7,500

Berbeza dengan kemungkiran janji di bawah AK 1950 pihak-pihak boleh menuntut remedi dalam bentuk pampasan atau ganti rugi di bawah seksyen 74 AK 1950 atau dalam bentuk pelaksanaan spesifik di bawah Akta Relif Spesifik 1950.

\section{c) Formaliti}

Selain itu, perbezaan antara kedua-dua prinsip ini juga boleh dilihat dari sudut formaliti. Janji dalam AK 1950 perlu dibuat secara formaliti sekiranya ia ditetapkan oleh undang-undang seperti yang ditetapkan dalam kontrak jual beli kenderaan, kontrak bangunan, kontrak sewaan dan sebagainya (Jeannie Paterson et al., 2005: 131). Contohnya dalam kes Affin Credit (Malaysia) Sdn. Bhd. v. Yap Yuen Fui [1983] 1 MLJ 169, Hakim Mahkamah Rayuan Persekutuan menolak tuntutan perayu dan menerima keputusan hakim terdahulu iaitu tawaran bertulis yang ditandatangani oleh defendan bukan satu tawaran yang diiktiraf oleh Akta Sewa Beli kerana plaintif tidak memenuhi syarat yang terkandung dalam akta tersebut dan tidak boleh menjadi penerimaan oleh plaintif suatu tawaran yang tidak wujud.

Kegagalan dalam memenuhi keperluan formaliti boleh menyebabkan kontrak tidak terbentuk dan tidak boleh dikuatkuasakan. Sebagaimana yang 
dinyatakan oleh Hakim Mahkamah Rayuan Abdul Malik Ishak dalam kes Bekalan Sains P \&C Sdn. Bhd. v. Bank Bumiputera Malaysia [2011] 5 MLJ 1 yang menyebut:

"untuk menjadikan kontrak sebagai rasmi (formalised) semua terma-terma dan syarat-syarat yang dinyatakan perlu dipenuhi. Kegagalan untuk memenuhi terma-terma atau syarat tidak akan membawa kepada pembentukan kontrak."

Manakala janji dalam undang-undang Islam tidak memerlukan formaliti kerana ia hanya satu perjanjian tambahan yang tidak memberi kesan kepada kontrak utama.

\section{d) Niat}

Menurut Clarence D. Ashley (1903: 319) janji yang dimaksudkan di bawah undang-undang kontrak ialah janji yang diniatkan untuk terikat di sisi undangundang. Manakala janji dalam undang-undang Islam hanyalah pemberitahuan atau komitmen untuk melakukan kontrak pada masa hadapan.

\section{e) Liabiliti}

Janji di bawah undang-undang Islam tidak membawa kepada liabiliti (tanggungan/kewajipan) kepada pembuat janji di mana pemilikan tidak akan dipindahkan kepada pembuat janji atau harga atau nilai aset tidak akan menjadi hutang oleh pembuat janji melainkan selepas kontrak sebenar dilakukan pada masa yang dipersetujui melalui tawaran ( $\bar{j} j \bar{a} b)$ dan penerimaan (qabūl) (Akademi Fiqh Antarabangsa, 2006; Azlin Alisa Ahmad et al., 2012: 10).

\section{CADANGAN DAN SARANAN}

Satu penegasan perlu dibuat oleh Majlis Penasihat Syariah (MPS) berkenaan dengan janji yang mempunyai kesan perundangannya tersendiri. Tambahan pula melalui pindaan Akta Bank Negara 2009 memberikan MPS kuasa yang luas dalam perjalanan operasi perbankan Islam di mana Akta tersebut memperuntukkan keperluan hakim Mahkamah Sivil merujuk kepada Majlis Penasihat Syariah (MPS) dalam perkara-perkara yang berkaitan dengan Perbankan dan Kewangan Islam dan keputusan yang dikeluarkan oleh MPS adalah mengikat mahkamah. ${ }^{3}$ Sehingga kini garis panduan tentang

$3 \quad$ Seksyen 56 (1) dan seksyen 57, Akta Bank Negara 2009. 
pengaplikasian prinsip janji masih dalam bentuk exposure draft yang telah dikeluarkan pada 6 Disember 2013.

Selain itu, Tun Abdul Hamid Mohamad (2009: 7-8) menyebut bahawa MPS bukan sahaja berperanan dalam menetapkan ketetapan hukum syarak sesuatu produk malah boleh menentukan persoalan mengenai undang-undang. Ini berdasarkan kepada perkara 4(k) Butiran I Senarai Persekutuan memberi kuasa kepada Parlimen menggubal undang-undang berhubung dengan penentuan hukum syarak bagi maksud persekutuan yang mana peruntukkan tersebut adalah sebagaimana berikut:

"Menentukan Hukum Syarak dan lain-lain undang-undang diri bagi maksud undang-undang persekutuan."

Peruntukan tersebut membolehkan penetapan hukum syarak untuk tujuan undang-undang persekutuan di buat oleh mana-mana badan persekutuan seperti Mahkamah Sivil atau Lembaga, Majlis atau Jawatankuasa yang ditubuh dengan kuat kuasa undang-undang persekutuan untuk tujuan itu. Oleh itu, MPS boleh diperbadankan di bawah peruntukan ini untuk tujuan tersebut dan dengan kuasa yang diberikan dalam peruntukan tersebut, MPS perlu mengambil dan memanfaatkan peluang ini untuk menetapkan undang-undang terutamanya dalam perkara janji supaya patuh dan selaras dengan undang-undang Islam dan juga Sivil yang boleh menjadi rujukan kepada hakim Mahkamah Sivil apabila berlaku pertikaian yang melibatkan kes-kes berkaitan kemungkiran janji.

\section{KESIMPULAN}

Konklusinya, Malaysia adalah sebuah negara yang unik kerana mengamalkan dwi-sistem dalam sistem kewangan dan perbankan Islam yang mana ia perlu patuh kepada dua sistem undang-undang yang berbeza yang berjalan seiring iaitu undang-undang Syariah dan juga sivil dan kesan akibat ketidakpatuhan kepada mana-mana undang-undang tersebut akan menyebabkan operasi perbankan Islam adalah tidak sah kerana kedua-dua undang-undang tersebut saling melengkapi antara satu sama lain (Ruzian Markom et al., 2011: 5). Keadaan ini sebagaimana dinyatakan di bawah seksyen 2 Akta Bank Negara 2009 iaitu:

"Perniagaan kewangan Islam ertinya apa-apa perniagaan kewangan dalam ringgit atau mata wang lain yang tertakluk kepada undang-undang yang dikuatkuasakan oleh Bank dan selaras dengan Syariah.", 
Senario ini juga sama dengan keadaan prinsip janji yang mana pengaplikasiannya perlu patuh dengan Syariah dalam masa yang sama juga tidak bercanggah dengan undang-undang sivil terutamanya AK 1950. Sebagaimana yang diketahui, konsep janji telah dipraktis atau diaplikasikan dalam produkproduk perbankan Islam di Malaysia lebih kurang 10 tahun apabila ia mula diperkenalkan pada awal tahun 2005 apabila Institusi Kewangan Islam (IFI) memperkenalkan produk-produk perbankan yang menyamai dengan Negaranegara di teluk Arab di bawah Gulf Cooperation Council (GCC) (Syeliya Md Zaini \& Nosrah Mohd Isa, 2011: 28). Ia merupakan satu tempoh yang cukup lama namun akan menjadi sia-sia apabila prinsip tersebut tidak boleh dikuatkuasakan di bawah AK 1950 dan sekiranya dikuatkuasakan di bawah AK 1950 membawa kepada percanggahan kepada Syariah kerana janji di bawah undang-undang Islam bukanlah membawa pembentukan kepada kontrak sebagaimana yang dimaksudkan oleh AK 1950.

Halangan undang-undang ini boleh membuatkan usaha yang dilakukan oleh pengamal-pengamal perbankan Islam dalam mencipta produk-produk baharu yang mengaplikasikan prinsip janji adalah tidak bermakna dan juga memberi imej yang buruk di mata masyarakat. Kerana itu, satu jawatankuasa Harmonisasi Undang-undang BNM diwujudkan yang berfungsi untuk mengharmonisasikan undang-undang sivil yang bercanggah dengan Islam dan seterusnya membolehkan kontrak-kontrak produk perbankan Islam boleh bergerak seiring dengan undang-undang sivil yang selaras dengan undangundang Islam.

\section{RUJUKAN}

Ahmad Hidayat Buang (2000). Studies in The Islamic Law of Contracts: The Prohibition of Gharar. Kuala Lumpur: International Law Book Services.

Abdul Mohaimin Noordin Ayus (2000). "Pembentukan Kontrak: Hubungan Prakontraktual dalam Undang-Undang Kontrak," dalam al-Ahkam: Undang-Undang Kontrak: Dasar, Konsep dan Maslahah, ed. Mahamad Arifin. Selangor: Dewan Bahasa \& Pustaka.

Ahmad Ibrahim (2000). "Undang-Undang Kontrak di Malaysia dan UndangUndang Islam," dalam al-Ahkam: Undang-Undang Kontrak: Dasar, Konsep dan Masalah, ed. Mahamad Arifin. Selangor: Dewan Bahasa \& Pustaka.

Accounting and Auditing Organisation for Islamic Financial Institutions (2007). Al-Ma'āyir al-Sharī'ah. Bahrain: Accounting and Auditing Organisation for Islamic Financial Institutions. 
Azlin Alisa Ahmad et al. (2012). "Bilateral Promise: Comparison from the Common Law and Islamic Law Perspective." Malayan Law Journal Articles, vol. 2.

Azlin Alisa Ahmad et al. (2012). "Kontrak Hadapan Mata Wang Asing Menurut Islam Sebagai Mekanisme Lindung Nilai: Analisis Penggunaan Wa'd." Islamiyyat, vol. 34.

Aznan Hasan, "Pengertian al-Wa'd, al-Wa'dan dan al-Muwa'adah." Muzakarah Cendekiawan Syariah Nusantara 2008, Jakarta, Indonesia, 27-28 Februari 2008.

Bank Negara Malaysia (2010). Resolusi Syariah dalam Kewangan Islam, ed. 2. Kuala Lumpur: Bank Negara Malaysia.

Bank Negara Malaysia (2012). Resolusi Syariah dalam Kewangan Islam. Kuala Lumpur: Bank Negara Malaysia.

Bank Negara Malaysia, "Murābahah," laman sesawang Bank Negara Malaysia, http://www.bnm.gov.my/guidelines/05shariah/CPMurabahah122013. pdf., dicapai pada 19 September 2014.

Bank Negara Malaysia (BNM), "The Shari'ah Advisory Council of Bank Negara Malaysia (the SAC) $157^{\text {th }}$ Meeting," http://www.bnm.gov.my/ index.php?ch=en_about\&pg=en_sac_updates\&ac $=445$, dicapai pada 19 Oktober 2015.

Clarance D. Ashley (1903). "What is A Promise in Law," Harvard Law Review, vol. xvi, no. 5 .

Hakimah Yaacob (2011). "Execution of Wa' ad in The Eye of S.1(2) of Contract Act 1950: Is It Valid?" Current Law Journal (CLJ), vol. 1.

Humayon Dar (2010). “Analysis: Promises in Islamic Banking.” NewHorizon: Global Perspective on Islamic Banking \& Insurance (174), JanuaryMarch.

Ismail Wisham et al. (2011). "Special Legal Features of The Islamic Wa'd or Pledge: Comparison with The Conventional Law on Promise within the Sphere of Islamic Finance," International Journal of Law and Management.

Ibn Hajar al-'Asqalānī (t.t.). Fath al-Bārī: Sharh Saḥ̄h al-Bukharī, vol. 5. Cairo: Maktabah al-Salafiyyah.

Jasani Abdullah \& Munawwaruzzaman Mahmud (2008). "Penggunaan Wa'ad dalam Kontrak Buyu', Ijarah \& Syirkah dari Perspektif Industri," Muzakarah Cendekiawan Syariah Nusantara, Jakarta, Indonesia, 27-28 Februari 2008. 
Jeannie Paterson, Andrew Robertson \& Peter Heffey (2005). Principles of Contract Law, ed. ke 2. Australia: Thomson \& Lawbook Co.

J.W Carter \& D.J Harland (2002). Contract Law in Australia, ed. ke 4. Australia: Reed International Books Australia Pty Limited.

Khairun Najmi Saripudin et al. (2012). "Application of Promise in Sukuk Musharakah Structure," Middle East Journal of Scientific Research.

Majallat Majma' al-Figh al-Islami (1998). vol. 2, no. 5. Jeddah: Majallat Majma' al-Fiqh al-Islami.

Marjan Muhammad, Hakimah Yaacob \& Shabana Hasan (2011). "The Bindingness and Enforceability of A Unilateral Promise (Wa'd): An Analysis from Islamic Law and Legal Perspectives." ISRA Research Paper No. 30.

Mohamad Akram Laldin (2009). "The Concept Paper of Promise and Bilateral Promise in Financial Contracts: A Fiqhi Perspective." Research Paper International Shari'ah Research Academy for Islamic Finance (ISRA), No. 4.

Muhammad Hisyam Mohamad (2014). "Promise (Wa'ad) and Contract ('Aqad) According to Islamic Law: A Comparative Study." Online Journal of Research in Islamic Studies, vol. 1, no. 1.

Mustafa "Afifi Halim et al. (2009). "Wa'ad (Unilateral Promise) dalam Perbankan Islam: Satu Analisis Berdasarkan Akta Kontrak 1950." International Seminar on Muamalat, Islamic Economic \& Finance (SMEKI09): Muamalat as Prescription to Global Economic Crisis, Department of Shariah, Faculty of Islamic Studies, UKM.

Nor Adila Mohd Nor \& Mohd Ashraf Aripin (2010). "Mechanism of al-Wa'd (Promise): TheoryAnd Application in Islamic Banking in Malaysia." Canadian Social Science, vol. 6, no. 1.

Noor Mohammed (1988). "Principles of Islamic Contract Law." Journal of Law and Religion, vol. 6, no. 1.

Nurdianawati Irwani Abdullah (2010). "Status and Implications of Promise (wa'd) in Contemporary Islamic Banking." Humanomics, vol. 26, no. 2.

Ruzian Markom, Helwa Mohammad Zainal \& Jasri Jamal (2011). "Kerangka Perundangan Sistem Kewangan Islam di Malaysia: Satu Tinjauan." Shariah Law Report, vol. 3.

Ruzian Markom et al. (2013). "Adjudication of Islamic Banking and Finance Cases in the Civil Courts of Malaysia." Europe Journal Law Economic, vol. 36 . 
Saadiah Mohamad, Azlin Alisa Ahmad \& Shahida Shahimi (2011). “ Innovative Islamic Hedging Products: Application of Wa'ad in Malaysian Bank Capital Market Value." The Journal of the Malaysian Finance Associatioan \& Bursa Malaysia, vol. 19, no. 1 \& 2.

Shabana Hasan \& Marjan Muhamad (2011). "Principles of Wa'ad and Muwa'adah: Their Application in Islamic Financial Contracts." ISRA International Journal of Islamic Finance, vol. 3, no. 2.

Siti Salwani Razali (2010). Islamic Law of Contract. Singapore: Cengage Learning Asia Pte Ltd.

S. Santhana Dass (2005). General Principles of Contract Law in Malaysia. Kuala Lumpur: Marsden Law Book.

Stephen Graw (2005). An Introduction to the Law of Contract, ed. ke-5. Sydney: Thomson Legal \& Regulatory.

Sudin Haron \& Wan Nursofiza Wan Azmi (2009). Islamic Finance and Banking System: Philosophies, Principles \& Practices. Selangor: McGrawHill, 2009.

Suraiya Osman \& Abdullah Jalil (2013). “An Islamic Perspective of Promise \& Its Relationshipwith the Islamic Law \& Contract.” Paper presented at The Isufi: International Seminar on Usul Fiqh, Nilai.

Syed Ahmad Alsagoff (2010). "Principles of the Law of Contract in Malaysia, ed. 3. Petaling Jaya: Lexis Nexis.

Syeliya Md Zaini \& Nosrah Mohd Isa (2011). "The Application of Wa'd in Islamic Banking Contract." Malaysian Accounting Review, vol. 10, no. 2.

Tun Abdul Hamid Mohamad (2009). "Perbankan Islam dan Takaful: Forum untuk Penyelesaian Isu Undang-Undang Hukum Syarak.” Muzakarah Ahli-Ahli Majlis Penasihat Syariah Institusi Kewangan di Malaysia kali ke-5, 17-19 Jun 2009).

Tun Abdul Hamid Mohamad (2010). "Interface Between Shariah \& Civil Law in Islamic Finance: Current Problems \& the Way Forward." Malaysian Law Conference 2010, Kuala Lumpur Convention Centre, 29-31 July 2010.

Tun Abdul Hamid Mohamad (2013). "Pengharmonian Undang-Undang Sivil dan Syariah dalam Perbankan dan Kewangan Islam di Malaysia." Institut Islam Hadhari Universiti Kebangsaan Malaysia, Sesi Diolog, 31 Januari 2013.

Visu Sinnadurai (2011). Law of Contract, ed. 4. Petaling Jaya: Lexis Nexis. 
Journal of Shariah Law Research (JSLR)

\section{Senarai Statut}

Akta Kontrak 1950.

\section{Senarai Kes}

Australian Woollen Mills Pty Ltd v. Commonwealth [1954] HCA 20; 1954 (92) CLR 424.

Bekalan Sains P\&C Sdn. Bhd. v. Bank Bumiputera Malaysia [2011].

Carlil v. Carbolic Smoke Ball Co [1893] QB 256.

Eckhardt Marine GMBH v. Sheriff, High Court of Malaya, Seremban \& Ors [2001] 4 MLJ 54.

Kopeks Sdn Bhd v. Bank Islam Malaysia Berhad [2012]4 MLJ 337.

Preston Corporation Sdn. Bhd. v. Edward Leong [1982] 2 MLJ 22. 